University of Nebraska - Lincoln

DigitalCommons@University of Nebraska - Lincoln

1985

\title{
An Evaluation of Condition Indices for Birds
}

Douglas H. Johnson

USGS Northern Prairie Wildlife Research Center, Douglas_H_Johnson@usgs.gov

Gary L. Krapu

USGS Northern Prairie Wildlife Research Center, gkrapu@usgs.gov

Kenneth J. Reinecke

USGS Northern Prairie Wildlife Research Center

Dennis G. Jorde

USGS Northern Prairie Wildlife Research Center

Follow this and additional works at: https://digitalcommons.unl.edu/usgsnpwrc

Part of the Other International and Area Studies Commons

Johnson, Douglas H.; Krapu, Gary L.; Reinecke, Kenneth J.; and Jorde, Dennis G., "An Evaluation of Condition Indices for Birds" (1985). USGS Northern Prairie Wildlife Research Center. 216.

https://digitalcommons.unl.edu/usgsnpwrc/216

This Article is brought to you for free and open access by the US Geological Survey at DigitalCommons@University of Nebraska - Lincoln. It has been accepted for inclusion in USGS Northern Prairie Wildlife Research Center by an authorized administrator of DigitalCommons@University of Nebraska - Lincoln. 


\section{AN EVALUATION OF CONDITION INDICES FOR BIRDS}

DOUGLAS H. JOHNSON, U.S. Fish and Wildlife Service, Northern Prairie Wildife Research Center, Jamestown, ND 58401 GARY L. KRAPU, U.S. Fish and Wildlife Service, Northern Prairie Wildlife Research Center, Jamestown, ND 58401 KENNETH J. REINECKE,' U.S. Fish and Wildlife Service, Northern Prairie Wildlife Research Center, Jamestown, ND 58401 DENNIS G. JORDE, ${ }^{2}$ U.S. Fish and Wildlife Service, Northern Prairie Wildlife Research Center, Jamestown, ND 58401

Abstract: A Lipid Index, the ratio of fat to fat-free dry weight, is proposed as a measure of fat stores in birds. The estimation of the index from field measurements of live birds is illustrated with data on the sandhill crane (Grus canadensis) and greater white-fronted goose (Anser albifrons). Of the various methods of assessing fat stores, lipid extraction is the most accurate but also the most involved. Water extraction is a simpler laboratory method that provides a good index to fat and can be calibrated to serve as an estimator. Body weight itself is often inadequate as a condition index, but scaling by morphological measurements can markedly improve its value.

J. WILDL. MANAGE. 49(3):569-575

Body weight and nutrient reserves, which are often used to characterize "condition," have been related to both survival (Lack 1966:276277) and breeding performance (Jones and Ward 1976) of birds (but see King and Murphy 1984). Assessing the condition of birds is therefore important in the study and management of bird populations (Bennett and Bolen 1978). Birds are capable of storing several nutrients for mobilization during critical periods of their life cycle. Although fat, protein, and $\mathrm{Ca}$ have each been identified as potentially limiting for breeding females (Ankney and MacInnes 1978), we believe that fat is the most frequent limiting nutrient during the year because of its numerous functions, including lipid source for egg synthesis (Raveling 1979), energy source during migration (Odum et al. 1964, Blem 1980) and food deprivation (Hanson 1962), and as insulation (Evans and Smith 1975). Protein and Ca requirements are relatively small except during egg production, when a larger turnover of these nutrients occurs (Robbins 1981).

Our purpose is to recommend a Lipid Index that represents fat stores of birds of various sizes and to indicate how the index can be estimated from measurements taken in the field on live birds. We also evaluate the performance of several published condition indices. The methods are illustrated with data on the sandhill crane and greater white-fronted goose.

\footnotetext{
${ }^{1}$ Present address: Patuxent Wildlife Research Center, Room 509, 820 South Street, Vicksburg, MS 39180.

${ }^{2}$ Present address: School of Forest Resources, Nutting Hall, University of Maine, Orono, ME 04469.
}

We thank R. Atkins, C. M. Boise, C. R. Frith, B. A. Hanson, C. Jorgenson, T. C. Tacha, and P. A. Vohs for their assistance in obtaining specimens from various study areas. R. R. Campbell, J. R. King, J. Longmuir, and D. W. Sparling provided valuable comments on an earlier draft of the report.

\section{STUDY AREAS AND METHODS \\ Study Areas}

All sandhill crane specimens were collected in 1978-79. From late February to mid-April, 119 were taken in the Platte River Valley of Nebraska. Additional samples included 28 taken in late April to early May near Last Mountain Lake in Saskatchewan, 20 taken during May or early June at Clarence Rhode National Wildlife Range in Alaska, 14 taken in late August or mid-October in central North Dakota, and 15 taken in mid-February near Muleshoe National Wildlife Refuge in Texas.

Most greater white-fronted geese (49) were collected from late February to early April in 1979-80 near the Platte River or in the Rainwater Basin of Nebraska. Six others were taken in late April or early May of 1979 in the Last Mountain Lake area.

\section{Field and Laboratory Methods}

Specimens were weighed and measured at field laboratories. Measurements included (flattened) Wing, (diagonal) Tarsus, and Culmen (post nares). External features and gonads were examined to ascertain the sex and age (young of the year and older; Lewis 1979) of each bird. Subspecies were identified according to Johnson and Stewart (1973). 
After all internal examinations were completed and contents were removed from the esophagus and gizzard, incisions in the carcass were closed to minimize desiccation, and the specimens were frozen for additional analysis. (Because cranes taken in Texas were held longer and may have desiccated, we omitted these birds from analyses involving water content.) Feathers were plucked and frozen specimens were transported to Raltech Scientific Services, Inc., Madison, Wisconsin, for analysis of body composition. Standard procedures (Horwitz 1975) were employed on homogenates of whole carcasses to estimate total water content, total lipid content, percentage protein, ash, and Ca. Lipid was extracted by the Soxhlet procedure using petroleum ether, with duplicate analyses for each specimen. Nitrogen was determined by the Kjeldahl method (Horwitz 1975) and converted to equivalent protein on the basis of the assumption that animal protein is $16 \% \mathrm{~N}$.

\section{A Model of Condition}

We employed the Lipid Index:

$$
\text { Lipid Index = Fat/Fat-free Dry Weight. }
$$

This index scales the fat content by a measure of structural size (Owen and Cook 1977:382), in recognition that $100 \mathrm{~g}$ of Fat has different meaning to a bird of $50 \mathrm{~g}$ lean weight than to one of $500 \mathrm{~g}$ lean weight. This scaling is particularly important for species such as the sandhill crane that vary considerably in size (e.g., Johnson and Stewart 1973). Schmidt-Nielsen (1979: 315) illustrated how a ratio such as Lipid Index is preferable to percentage data for portraying the importance of a body constituent.

For the purpose of statistical modeling, we made the transformation CI $=\log$ (Lipid Index +1 ) because of the allometric nature of the variables and because logarithms are generally suited for linearizing ratios. The transformation produces a function that is more readily approximated by a regression equation. The constant 1 is added before taking logarithms simply to smooth the function, particularly for small values of Fat.

Because Dry Weight $=$ Fat + Fat-free Dry Weight, CI can be expressed as

$$
\mathrm{CI}=\log \left(\frac{\text { Dry Weight }}{\text { Fat-free Dry Weight }}\right) .
$$

We chose to model the logarithm of Fat-free Dry Weight (FFDW) as a linear function of logarithms of the various morphological measurements, i.e.,

$$
\begin{aligned}
\log \text { FFDW }= & b_{0}+b_{1} \log \text { Tarsus } \\
& +b_{2} \log \text { Wing } \\
& +b_{3} \log \text { Culmen }
\end{aligned}
$$

and to model log Dry Weight as a linear function of Weight and (possibly) the morphological measurements:

$$
\begin{aligned}
\log \mathrm{DW}= & \mathrm{c}_{0}+\mathrm{c}_{1} \log \text { Tarsus }+\mathrm{c}_{2} \log \text { Wing } \\
& +\mathrm{c}_{3} \log \text { Culmen }+\mathrm{c}_{4} \log \text { Weight. }
\end{aligned}
$$

Then

$$
\begin{aligned}
\text { CI }= & \log \left(\frac{D W}{\text { FFDW }}\right) \\
= & \left(c_{0}-b_{0}\right)+\left(c_{1}-b_{1}\right) \log \text { Tarsus } \\
& +\left(c_{2}-b_{2}\right) \log \text { Wing } \\
& +\left(c_{3}-b_{3}\right) \log \text { Culmen } \\
& +c_{4} \log \text { Weight. }
\end{aligned}
$$

Hence, CI can be modeled directly in terms of Weight, Tarsus, Wing, and Culmen.

\section{Statistical Methods}

We developed the predictive equation with a robust regression procedure, which reduced the effect of any aberrant data points. We wanted to portray the general relationship within a group of birds, whereas ordinary regression analysis tends to distort the predictive equation if one or more individuals deviate markedly from the rest.

We employed the iterative weighted least squares procedure (Mosteller and Tukey 1977). We first calculated the usual regression equation and then used residuals from the equation (predicted values minus actual ones) as weights in another iteration. We gave points lying close to the regression line weights near one and points far from the line smaller weights. We next calculated the second regression, employing these weights, which produced another regression line and new residuals. We then used these residuals as weights in the third iteration, and so on. The process converged rapidly, with a net effect that deviant observations received little weight in the analysis, and the regression line fit the main swarm of points.

The weights employed were

$$
w(u)=\left\{\begin{array}{ccc}
\left(1-u^{2}\right)^{2} & \text { if } & u<1 \\
0 & \text { if } & u \geq 1
\end{array}\right.
$$


where $\mathrm{u}$ is the residual from the regression equation divided by six times the median absolute deviation of all residuals, a robust analog of the standard deviation (Mosteller and Tukey 1977:358).

\section{RESULTS}

\section{Sandhill Crane}

The sandhill cranes in our samples included both lesser (G. c. canadensis) and the Canadian (G. c. rowani) subspecies. These subspecies differ in breeding range and also in various morphological measurements including Wing, Tarsus, and Culmen (Johnson and Stewart 1973). Cranes differed by subspecies as well as by sex on the measurements of these morphological features and on Body Weight, Dry Weight, Fat, and Fat-free Dry Weight. Lipid Indices were similar in all groups. While developing an expression for estimating Lipid Index, we did not use the sex of a bird, because that information would normally not be available from live cranes and its use would preclude the Condition Index from serving as a field technique.

After three iterations of the regression analysis, in which each of the 177 observations was weighted inversely by its extent of departure from the model fitted on the previous occasion, the process stabilized to the following equation:

$$
\begin{gathered}
\mathrm{CI}=3.447+1.183 \log \text { Weight } \\
(1.033)(0.064) \\
-1.179 \log \text { Wing } \\
(0.220) \\
-0.319 \log \text { Tarsus } \\
(0.135) \\
-0.866 \log \text { Culmen } \\
(0.110)
\end{gathered}
$$

Standard errors of the coefficients are in parentheses. The coefficient of determination was $R^{2}=$ 0.701 .

We tested the model by performing a threefactor analysis of variance (ANOVA) on residuals calculated from the model. No effects due to subspecies or sex were significant, indicating that the model performed equally well for all of those groups. The age effect was significant $(P=0.03)$; the predictive equation tended to underestimate Lipid Index among young birds and to overestimate it slightly for old birds.

A similar procedure was followed to develop an estimating equation for log Fat. A separate equation was found for each age. For adults, two iterations produced:

$$
\begin{aligned}
\log \text { Fat }= & 1.518+3.800 \log \text { Weight } \\
& (2.485)(0.172) \\
& -2.069 \log \text { Wing } \\
& (0.519) \\
- & 0.955 \log \text { Tarsus } \\
& (0.356) \\
- & 2.009 \log \text { Culmen } \\
& (0.297)
\end{aligned}
$$

with $R^{2}=0.786$. Culmen did not significantly relate to Fat among young cranes. After two iterations the equation converged to

$$
\begin{aligned}
\log \text { Fat }= & 8.400+4.679 \log \text { Weight } \\
(11.965)(0.821) & -4.190 \log \text { Wing } \\
& (2.660) \\
- & 2.836 \log \text { Tarsus, } \\
& (1.422)
\end{aligned}
$$

where $R^{2}=0.607$.

\section{White-Fronted Goose}

Male white-fronted geese exceeded females on the basic morphological measurementsWing, Tarsus, and Culmen, and on Weight, Dry Weight, and Fat-free Dry Weight. In Nebraska, males contained more Fat than did females but the reverse held in Saskatchewan. Within sex, young geese had smaller average values of most measurements except Tarsus and Culmen. Average Lipid Indices did not differ significantly by age or sex.

In developing a predictive equation for CI, we found that Fat-free Dry Weight could be adequately modelled by Tarsus and Wing measurements, and that an estimator of CI could be based on Tarsus, Wing, and Weight values. Two iterations were adequate to reduce the effect of outlying observations. The final model was

$$
\begin{aligned}
\mathrm{CI}= & 6.271+1.429 \log \text { Weight } \\
& (2.256)(0.104) \\
- & 0.990 \log \text { Tarsus } \\
& (0.277) \\
- & 2.089 \log \text { Wing } \\
& (0.428)
\end{aligned}
$$

with a coefficient of determination of $R^{2}=$ 0.799 .

We assessed the adequacy of equation 4 by 
subjecting the residuals to a three-factor ANOVA. No effect due to age, sex, or location was significant, indicating that the estimating equation performed equally well on all groups of birds.

The robust regression procedure yielded the following estimating equation for log Fat after two iterations:

$$
\begin{aligned}
\log \text { Fat }= & 6.575+3.255 \log \text { Weight } \\
& (3.602)(0.162) \\
& -3.412 \log \text { Wing } \\
& (0.689) \\
- & 1.275 \log \text { Tarsus } \\
& (0.438)
\end{aligned}
$$

with $R^{2}=0.888$.

\section{A COMPARISON OF CONDITION INDICES}

A variety of methods have been employed to estimate the lipid content of animals and to evaluate their condition. Lipid extraction (see Horwitz 1975) provides the standard against which others are evaluated, but requires the collection of specimens and is both expensive and time-consuming. Other methods are based on body weight-either alone or in combination with morphological information, on water content, or on the size of specific fat depots. We evaluated, with our samples of cranes and geese, several published condition indices on the basis of how well they could predict either Fat or Lipid Index. The squared correlation coefficient indicates how close the values of a measure and the true value are to a straight line. For those measures that attempt to predict Fat, we also determined the bias shown by the predictor when applied to the birds in our samples. A high $r^{2}$ suggests that the measure has merit as an index; a high $r^{2}$ together with a small bias indicates that the measure is also useful for predicting Fat, at least in our samples.

\section{Body Weight}

Gross body weight is an index to fat content that can be taken readily from live birds without harm. Among cranes (Table 1), Body Weight alone correlated only fairly well with Fat $\left(r^{2}=0.416\right)$ and poorly with Lipid Index $\left(r^{2}=0.166\right)$. For sandhill cranes, Iverson and Vohs (1982) developed the following equation as a predictor of Fat from Body Weight:

$$
\text { Fat }=-811+0.41(\text { Body Weight }) \text {. }
$$

Among our cranes, this equation consistently overestimated the actual value of Fat (Table 1). For geese (Table 2), Body Weight was closely related to Fat $\left(r^{2}=0.711\right)$ and fairly closely associated with Lipid Index $\left(r^{2}=0.486\right)$.

\section{Scaled Body Weight}

Although body weight is often an adequate index to condition, many investigators (e.g., Connell et al. 1960, King and Farner 1966) recognized the desirability of accounting for structural differences in size. Weight divided by wing length has been used in many passerine studies (Odum et al. 1964) and some waterfowl work (Owen and Cook 1977). Harris (1970) and others employed weight divided by the product of bill length times keel length. Such indices are easily taken from live birds, but in general their validity is untested.

Some indices have been proposed for and tested on a few species (e.g., Bailey 1979, Wishart 1979). Iverson and Vohs (1982) proposed several predictors of Fat for sandhill cranes based on ratios of body weight to various morphological measurements. We tested several of these using our crane data:

$$
\begin{aligned}
& \text { Fat }= \\
& \quad-996+34.3(\text { Body Weight/Culmen }) \\
& \text { Fat }= \\
& \quad-1,193+243(\text { Body Weight/Wing }) \\
& \text { Fat }= \\
& \quad-1,198+109(\text { Body Weight/Tarsus })
\end{aligned}
$$

The wing measurement employed in equation 7 is unflattened wing, in contrast to the flattened wing measurement we employed earlier. We evaluated five indices involving Body Weight in combination with morphological measurements: Body Weight/Wing (equation 7 for cranes), Body Weight/Culmen (equation 6 for cranes), Body Weight/Tarsus (equation 8 for cranes), our equation 3 (for cranes), and our equation 4 (for geese).

Combining Body Weight with a structural measurement considerably improved the correlation with Fat and Lipid Index among cranes (Table 1). For the latter quantity, equation 3 of this paper clearly had the highest correlation. All equations of Iverson and Vohs (1982) consistently and significantly $(P<0.001)$ overestimated the fat content of the cranes in our samples. Incorporation of morphological data 
Table 1. Squared correlation coefficients $\left(r^{2}\right)$ relating various condition indices to Fat and Lipid Index, for sandhill cranes.

\begin{tabular}{|c|c|c|c|}
\hline \multirow[b]{2}{*}{ Condition index } & \multicolumn{2}{|c|}{ Fat } & \multirow{2}{*}{$\begin{array}{c}\begin{array}{c}\text { Lipid } \\
\text { Index }\end{array} \\
r^{2}\end{array}$} \\
\hline & $r^{2}$ & $\operatorname{Bias}(\mathrm{g})$ & \\
\hline $\begin{array}{l}\text { Body weight } \\
\text { Equation } 5\end{array}$ & $\begin{array}{l}0.416 \\
0.416\end{array}$ & 246.7 & 0.166 \\
\hline \multicolumn{4}{|l|}{ Body weight + size } \\
\hline $\begin{array}{l}\text { Wing } \\
\quad \text { Equation } 7\end{array}$ & $\begin{array}{l}0.567 \\
0.567\end{array}$ & 297.2 & 0.297 \\
\hline $\begin{array}{l}\text { Culmen } \\
\text { Equation } 6\end{array}$ & $\begin{array}{l}0.640 \\
0.640\end{array}$ & 160.7 & 0.472 \\
\hline $\begin{array}{l}\text { Tarsus } \\
\quad \text { Equation } 8\end{array}$ & $\begin{array}{l}0.550 \\
0.550\end{array}$ & 406.1 & 0.350 \\
\hline Equation 3 & 0.675 & & 0.597 \\
\hline \multicolumn{4}{|l|}{ Water extraction } \\
\hline $\begin{array}{l}\% \text { water } \\
\text { Child and Marshall- }\end{array}$ & 0.870 & & 0.894 \\
\hline $\begin{array}{l}\text { original } \\
\text { Child and Marshall- }\end{array}$ & 0.965 & -82.5 & 0.814 \\
\hline $\begin{array}{l}\text { derived } \\
\text { Campbell and Leather- }\end{array}$ & 0.969 & 4.5 & 0.808 \\
\hline $\begin{array}{l}\text { land-original } \\
\text { Campbell and Leather- }\end{array}$ & 0.969 & -103.9 & 0.803 \\
\hline land-derived & 0.971 & -0.1 & 0.784 \\
\hline
\end{tabular}

improved the prediction of fat among geese (Table 2). The predictor developed in the present paper (equation 4) correlated more closely with both Fat and Lipid Index than did any others based on weight and a size measurement.

\section{Percent Water}

Laboratory techniques simpler than lipid extraction involve the estimation of fat (and sometimes protein) from the water content of birds. Three such methods can be identified. The first is simply the percentage of water in the carcass. Because little water is required in the storage of fat (Odum et al. 1964, Blem 1980: 203), compared with protein, birds with higher fractions of water tend to have lower fat content, and vice versa. Bailey (1979) and Wishart (1979) found strong negative correlations between percent water and fat; Peterson and Ellarson (1979) suggested a similar relation. Woodall (1978) obtained a weaker correlation in his sample of 14 red-billed ducks (Anas erythrorhyncha).

We found excellent correlations between percent water and Fat $\left(r^{2}=0.870\right.$ for cranes and $r^{2}=0.813$ for geese). Percent water correlated even more closely with Lipid Index $\left(r^{2}=\right.$ 0.894 for cranes and $r^{2}=0.858$ for geese).
Table 2. Squared correlation coefficients $\left(r^{2}\right)$ relating various condition indices to Fat and Lipid Index, for white-fronted geese.

\begin{tabular}{|c|c|c|c|}
\hline \multirow[b]{2}{*}{ Condition index } & \multicolumn{2}{|c|}{ Fat } & \multirow{2}{*}{$\begin{array}{c}\begin{array}{c}\text { Lipid } \\
\text { Index }\end{array} \\
r^{2}\end{array}$} \\
\hline & $r^{2}$ & Bias (g) & \\
\hline Body weight & 0.711 & & 0.486 \\
\hline \multicolumn{4}{|l|}{ Body weight + size } \\
\hline $\begin{array}{l}\text { Wing } \\
\text { Culmen } \\
\text { Tarsus } \\
\text { Equation } 4\end{array}$ & $\begin{array}{l}0.805 \\
0.764 \\
0.812 \\
0.834\end{array}$ & & $\begin{array}{l}0.626 \\
0.608 \\
0.662 \\
0.763\end{array}$ \\
\hline \multicolumn{4}{|l|}{ Water extraction } \\
\hline $\begin{array}{l}\% \text { water } \\
\text { Child and Marshall- } \\
\quad \text { original }\end{array}$ & 0.813 & -88.0 & 0.858 \\
\hline Child and Marshall- & 0.989 & 0.2 & 0.906 \\
\hline $\begin{array}{l}\text { Campbell and Leather- } \\
\text { land-original } \\
\text { Campbell and Leather- }\end{array}$ & 0.989 & -129.9 & 0.912 \\
\hline land-derived & 0.990 & -6.9 & 0.897 \\
\hline
\end{tabular}

\section{Child-Marshall Method}

The second water extraction method is based on the relative constancy of water as a fraction of fat-free weight. Odum et al. (1964), Child (1969), and Child and Marshall (1970) demonstrated this relation among migrant birds, following earlier work with mammals. From this relation, once the average ratio of water to fat-free weight (WFFW) is known, the fat content can be estimated as Weight - Water/ WFFW (Child and Marshall 1970). Child and Marshall (1970) found an average WFFW of 0.687 for several small passerine species. We used the Child and Marshall (1970) procedure both with their coefficient and with one we determined from our samples.

Our data for cranes yielded WFFW $=0.710$ for young and WFFW $=0.705$ for adults. Among our geese, WFFW averaged 0.724 for young and 0.717 for adults. The Child-Marshall procedure gave values that correlated closely with Fat and, to a lesser extent, Lipid Index among both cranes (Table 1) and geese (Table 2 ). The strength of association was the same regardless of whether the original or derived coefficients were used, but the original ones led to modest negative biases.

\section{Campbell-Leatherland Method}

The third method for using water extraction data involves two assumptions: (1) that water is 
in a constant ratio (say WP) to protein; and (2) that fat plus protein together compose a constant fraction (K) of total dry weight. Summers et al. (1965) suggested this procedure, and Campbell and Leatherland (1980) described the earlier uses and applied it to snow geese (Chen caerulescens). An advantage of this method is that it estimates both fat and protein. Campbell and Leatherland found average values of WP to be 2.99 for immature ( $<2$ years old) snow geese and 2.88 for adults. Average values for $\mathrm{K}$ were 0.83 for immatures and 0.82 for adults.

We obtained the following averages for WP from our cranes: 3.350 for young females, 3.160 for adult females, 3.177 for young males, and 3.096 for adult males. Values of $\mathrm{K}$ did not vary by age or sex, so we employed the average $\mathrm{K}=$ 0.857 . For geese, averages of WP were 3.28 for immatures and 3.17 for adults, each value about 0.3 higher than corresponding means from Campbell and Leatherland (1980). We found that $K$ did not depend on age or sex, so we used the pooled mean of $\mathrm{K}=0.896$. This method performed as well as the Child-Marshall procedure (Tables 1,2). Again, using the original coefficients caused modest downward biases in estimates of Fat.

\section{Fat Depots}

A final method of estimating lipid content is to dissect and weigh particular fat depots (Hanson 1962, Baker 1975, Woodall 1978, Thomas et al. 1983). Because fat is deposited, not uniformly among all depots, but in a fairly precise sequence (Blem 1976:675), individual depots may not faithfully reflect the total fat content of a bird. Baldassarre et al. (1980) suggested that an index to lipid depots could be provided by ultrasonic devices. Helms and Drury (1960) proposed fat classes based on visible fat for two passerine species. A visual index of the abdominal fat depot was proposed by Owen (1981) for barnacle geese (Branta leucopsis), and McNeil (1969) offered equations to predict fat content of several shorebird species from a visual index of subcutaneous fat deposits. We did not evaluate any methods based on fat depots.

In conclusion, estimates of Lipid Index and total fat are valuable for a variety of management and research purposes, and both should be obtained whenever feasible. The Lipid Index is more appropriate when comparisons are to be made among age, sex, or taxonomic groups that differ markedly in size, whereas total fat is more valuable for within-species analyses that address the contribution of nutrient reserves to egg production, migration, and maintenance.

Various methods have been put forth for estimating fat content of wild birds (but little has been done regarding Lipid Index). Certain features of these techniques can be identified. Fat extraction is the most accurate of the methods but requires a dead specimen and sophisticated equipment.

Water extraction is a simpler but fairly timeconsuming laboratory procedure. Percent water is a good index to fat content, but can be considerably improved by either the Child and Marshall (1970) or the Campbell and Leatherland (1980) equations. If fat can be extracted from a representative subsample of birds, either of these equations can be calibrated to provide a good estimator of fat, in addition to an index. The equations calculated with published coefficients offer good indices to fat. The Campbell and Leatherland method has the advantage of also estimating protein content.

Examination of lipid depots provides a good index to fat and may give adequate estimates as well, but its performance as an estimator should be verified on each sample of birds. The method is relatively simple and need not destroy the entire specimen.

Body weight alone is a fair index to fat, but can be misleading among groups of birds in which size differences are appreciable. Scaling weight by a structural measurement will usually improve its value as an index and may serve as a good predictor if the coefficients are derived from the same group of birds. Regression equations in logarithms of measurements, such as those developed in this report, have greater flexibility than equations involving ratios, such as Weight/Wing, which restrict the coefficients of the numerator and of the denominator to be equal but of opposite sign. Robust fitting methods provide predictive equations less influenced by unusual observations.

\section{LITERATURE CITED}

ANKNEY, C. D., AND C. D. MaCInNEs. 1978. Nutrient reserves and reproductive performance of female lesser snow geese. Auk 95:459-471.

BAILEY, R. O. 1979. Methods of estimating total lipid content in the redhead duck (Aythya americana) and an evaluation of condition indices. Can. J. Zool. 57:1830-1833. 
BAKER, A. J. 1975. Lipid levels in the South Island pied oystercatcher (Haematopus ostralegus finschi). N.Z. J. Zool. 2:425-434.

Baldassarke, G. A., R. J. Whyte, and E. G. Bolen. 1980. Use of ultrasonic sound to estimate body fat depots in the mallard. Prairie Nat. 12:79-86.

BENNETT, J. W., AND E. G. Bolen. 1978. Stress response in wintering green-winged teal. J. Wildl. Manage. 42:81-86.

Blem, C. R. 1976. Patterns of lipid storage and utilization in birds. Am. Zool. 16:671-684.

- 1980. The energetics of migration. Pages 175-224 in S. A. Gauthreaux, ed. Animal migration, orientation, and navigation. Academic Press, New York, N.Y.

Campbell, R. R., and J. F. Leatherland. 1980. Estimating body protein and fat from water content in lesser snow geese. J. Wildl. Manage. 44:438-446.

ChILD, G. I. 1969. A study of nonfat weights in migrating Swainson's thrushes (Hylocichla ustulata). Auk 86:327-338.

- AND S. G. Marshall. 1970. A method of estimating carcass fat and fat-free weights in migrant birds from water content of specimens. Condor 72:116-119.

Connell, C. E., E. P. Odum, and H. Kale. 1960. Fat-free weights of birds. Auk 77:1-9.

Evans, P. R., AND P. C. SMITH. 1975. Studies of shorebirds at Lindisfarne, Northumberland. 2. Fat and pectoral muscle as indicators of body condition in the bar-tailed godwit. Wildfowl 26 : 64-76.

Hanson, H. C. 1962. The dynamics of condition factors in Canada geese and their relation to seasonal stresses. Arc. Inst. North Am. Tech. Publ. 12. $68 \mathrm{pp}$.

HARRIS, H. J., JR. 1970. Evidence of stress response in breeding blue-winged teal. J. Wildl. Manage. 34:747-755.

Helms, C. W., AND W. H. Drury, JR. 1960. Winter and migratory weight and fat field studies on some North American buntings. Bird-Banding 31:1-40.

HoRwITZ, W., editor. 1975. Official methods of analysis. 12th ed. Assoc. Off. Anal. Chem., Washington, D.C. 1094pp.

Iverson, G. C., AND P. A. VoHS, JR. 1982. Estimating lipid content of sandhill cranes from anatomical measurements. J. Wildl. Manage. 46: 478-483.

Johnson, D. H., AND R. E. STEwart. 1973. Racial composition of migrant populations of sandhill cranes in the northern plains states. Wilson Bull. 85:148-162.

JONES, P. J., AND P. WARD. 1976. The level of reserve protein as the proximate factor controlling the timing of breeding and clutch-size in the red-billed quelea Quelea quelea. Ibis 118: 547-574.
KING, J. R., AND D. S. FARnER. 1966. The adaptive role of winter fattening in the white-crowned sparrow with comments on its regulation. Am. Nat. 100:403-418.

- AND M. E. Murphy. 1984. Periods of nutritional stress in the annual cycles of homeotherms: fact or fiction? Am. Zool. In Press.

LACK, D. 1966. Population studies of birds. Clarendon Press, Oxford, U.K. 34lpp.

LEWIS, J. C. 1979. Field identification of juvenile sandhill cranes. J. Wildl. Manage. 43:211-214.

MCNEIL, R. 1969. La détermination du contenu lipidique et de la capacité de vol chez quelques espéces d'oiseaux de rivage (Charadriidae et Scolopacidae). Can. J. Zool. 47:525-536.

Mosteller, F., AND J. W. Tukey. 1977. Data analysis and regression. Addison-Wesley Publ. Co., Reading, Mass. 588pp.

Odum, E. P., D. T. Rogers, AND D. L. Hicks. 1964 Homeostasis of the nonfat components of migrating birds. Science 143:1037-1039.

OWEN, M. 1981. Abdominal profile-a condition index for wild geese in the field. J. Wildl. Manage. 45:227-230.

- AND W. A. Cook. 1977. Variations in body weight, wing length and condition of mallards (Anas platyrhynchos) and their relationship to environmental changes. J. Zool., London 183: 377-395.

Peterson, S. R., AND R. S. Ellarson. 1979 Changes in oldsquaw carcass weight. Wilson Bull. 91:288-300.

Raveling, D. G. 1979. The annual cycle of body composition of Canada geese with special reference to control of reproduction. Auk 96:234252.

RobBINS, C. T. 1981. Estimation of the relative protein cost of reproduction in birds. Condor 83: $177-179$.

SChMidt-Nielsen, K. 1979. Animal physiology. 2nd ed. Cambridge Univ. Press, Cambridge, U.K. 560pp.

Summers, J. D., S. J. Slinger, and G. C. Ashton. 1965. The effect of dietary energy and protein on carcass composition with a note on a method for estimating carcass composition. Poult. Sci. 44: 501-509.

Thomas, V. G., J. K. Mainguy, and J. P. Prevett 1983. Predicting fat content of geese from abdominal fat weight. J. Wildl. Manage. 47:11151119.

WISHART, R. A. 1979. Indices of structural size and condition of American wigeon (Anas americana). Can. J. Zool. 57:2369-2374

WoOdall, P. F. 1978. Omental fat: a condition index for redbilled teal. J. Wildl. Manage. 42: $188-190$.

Received 13 April 1984.

Accepted 19 September 1984. 